\title{
Pembentukan Karakter Menurut Ki Hajar Dewantara dan Relevansinya dengan Pendidikan Islam
}

\section{Miftahus Salam}

STAI At-Taqwa Bondowoso

miftahus01@gmail.com

\section{Article History:}

Received : 05-06-2019

Revised : 21- 08-2019

Accepted : 05-09-2019

\begin{abstract}
: character building is an integral part of the main objective of education. Not only related to the development of scientific insights, but Islamic education is also oriented to the formation of morals (character). In Indonesia, the educational figure Ki Hajar Dewantara has a unique perspective on education and its strategy in shaping students' character. In this research, several problem formulations are proposed, including 1) what is the method of character building according to Ki Hajar Dewantara ?, 2) How is the character-building method in Islamic education? This type of research is research (Library Research), which takes library materials that have something to do with the problem under study. This research concludes that character education, according to Ki Hajar Dewantara consists of among, ngemong and among as well as ngerti, ngrasa and nglakoni. Meanwhile, its relevance to Islamic education is the concept of character building Ki Hajar combining morality, intellect and spirituality, the three of which are circularly applicable in the concept of Islamic faith, which is not only limited to believing and understanding, but also implementing it in everyday life.
\end{abstract}

Keywords: Character Education, Ki Hadjar Dewantara, Islamic Education

\section{Pendahuluan}

Pendidikan adalah suatu proses dalam rangka mempengaruhi peseta didik supaya mampu menyesuaikan diri sebaik mungkin dengan lingkungannya, dan dengan demikian atau menimbulkan perubahan dan berbagai persoalan yang muncul seiring dengan perkembangan zaman. Tindakan amoral yang dilakukan oleh generasi mudah saat ini mau tidak mau harus disadari memancing keprihatinan yang mendalam dari semua kalangan. Gencarnya desakan dan dorongan dari masyarakat akan urgensi pendidikan karakter dalam pendidikan nasional menunjukan ketidakpuasan masyarakat akan kualitas lembaga pendidikan di indonesia. Kondisi ini membawa kesepakatan bahwa sudah saatnya pendidikan karakter dilaksanakan secara sistematis strategis dan menyeluruh sekolah sehingga pendidikan karakter menjadi efektif dalam pembentukan pribadi para siswa. ${ }^{1}$

Secara terminologis pendidikan karakter menurut Thomas Lickona adalah pendidikan untuk membentuk kepribadian seorang melalui pendidikan budi pekerti, yang hasilnya terlihat dalam tindakan nyata seseorang, menurut Aristoteles bahwa

1Zubaidi, Desain karakter (Jakarta: Preneda Media Group, 2011), 2 
pendidikan karakter itu erat kaitannya dengan kebiasaan yang kerap dimanifestasikan dalam tingkah laku. ${ }^{2}$

Di Indonesia pendidikan karakter sudah lama di tekankan oleh penggagas pertama kali yaitu Ki Hajar Dewantara yang mengemukakan konsep pendidikan karakter dengan menekankan pada pembentukan karakter melalui pembiasaan pembuatan.

Namun semakin berkembangnya zaman pendidikan karakter yang di tujukan untuk membentuk karakter siswa agar lebih baik kini masih di perlukan kerja keras untuk melawan era modernisasi dalam mendidik karakter yang religius, bertanggung jawab dan cinta tanah air. Dalam mendidik karakter anak, agar implementasi pendidikan karakter di sekolah dapat berhasil, maka syarat utama yang harus dipenuhi diantaranya: 1) Teladan dari guru, tenaga kependidikan, pimpinan sekolah dan para pemangku kebijakan di sekolah; 2) Pendidikan karakter harus dilakukan secara konsisten dan terus menerus; 3) Penanaman nilai-nilai karakter yang utama. ${ }^{3}$

Krisis moral khususnya pada pemuda-pemudi Indonesia yang mempunyai problematika dalam hal karakternya, seperti yang dikemukakan oleh Badan Narkotika Nasional (BNN). Bahwa pemakai narkoba di Indonesia sekitar 1,5\% diantara penduduk Indonesia merupakan pemakai narkoba 78\% korban yang tewas akibat narkoba yang berusia 19-21 tahun, yang berarti dalam usia masih pelajar. Perilaku kehidupan seksual yang bebas, gaya hidup yang pola perilaku pelajar di kota-kota besar. Adapun pertumbuhan budaya seks, yakni kehamilan di luar nikah rata-rata $17 \%$ pertahun dan pelaku bermuara pelaku aborsi hamil di luar nikah 2,4 juta jiwa pertahun Kemudian temuan HIV/AIDS menurut sumber Riset Kementrian Kesehatan pada tahun 2010 adalah HIV/AIDS mencapai 21,770 kasus, AIDS positif 47.157, HIV positif 48,1\% (pelakunya usia 20-29 tahun) yang juga dilakukan oleh usia pelajar, Penularan di kalangan heteroseksual 49,35\%, Penularan melalui jarum/IDU 40,4\%, .

Kasus tawuran antar pelajar dan mahasiswa bermunculan hampir setiap tahun di beberapa kota besar. Hasil survey FEKMI (2003) menunjukan bahwa 1573 orang remaja atau pemuda pemah $54 \%$ berkelahi, $87 \%$ bebohong, 8,9\% mencoba narkoba, $28 \%$ merasa kekerasan adalah hal biasa, Melukai diri sendiri 17\%, Ketergantungan obat atau minuman 17\%, Depresi 12\%, 47\% remaja mengaku nakal di sekolah, 33\% tidak memedulikan peraturan sekolah.

Masalah sosial yang terjadi juga diantaranya kiminilitas remaja, adapun penyebab utama terjadinya kriminalitas di kalangan remaja adalah 93\% anak-anak pernah mengalami tindak kekerasan dirumah+sekolah (save the children di 10 provinsi), $82 \%$ remaja menganggap orang tua otorier, $50 \%$ mengaku mendapat hubungan fisik, 399\% mengatakan orang tua pemarah, Ayub sani: sekarang anak fabia sekolah, takut guru galak, ruangan panas, takut di palak teman.

Melihat kenyataan diatas sangat penting tetap berpegang teguh pada agama yaitu al qur'an dan As-sunnah agar karakter manusia tetap melekat meski asing pada zaman

2 Dharma Kusuma dkk, Pendidikan Karakter (Bandung: Remaja Rosdakarya. 2012), 2

${ }^{3}$ Agus Wibowo, Pendidikan Karakter Strategi mebangun karakter bangsa berperadaban (Jogjakarta: Pustaka Pelajar, 2012), 25 
ini. Karena itulah karakter yang terbaik.Adalah tetap menjadi orang asing pada zaman ini, yang dimaksud berbeda yaitu menjadi ghorib berarti berbeda dengan yang lain dengan kata yang lain berbeda dengan zaman, yaitu karakter yang siap untuk menghadapi perubahan zaman.

Begitu pula Al-quran yang diperuntukan untuk seluruh alam karena al'quran sebagai rahmatilil alamin untuk zaman dahulu sampai zaman akhir akan sebagai petunjuk bagi makhluk. Dan di al-qur'an semua aspek kehidupan telah dijelaskan tergantung kita mau dipelajarinnya atau tidak. Dan barang siapa yang mau untuk mempelajarinnyya maka niscaya pengetahuan yang lurus akan mengikutinya.

Selain itu sebagai bangsa Indonesia yang cinta adat istiadat indonesia maka lebih baik jika kita melihat perjuangan bapak pendidikan kita Ki Hajar Dewantara dalam pendidikan tentang pendidikan karakter dizaman pendidikan karakter yang selalu menjadi bahan pembicaraan dari setiap kalangan. Untuk melaksakan pendidikan karakter maka diperlukan metode untuk membentuk karakter siswa. Karena keberhasilan dalam membentuk karakter siswa mempengaruhi oleh metode yang di ambil dalam pembentukannya. Dari penjelasan-penjelasan diatas, maka penting untuk mengkaji bagaimana relasi dan relevansi pembentukan karakter dalam pendidikan dalam perspektif Ki Hajar Dewantara serta relevansinya dengan Pendidikan Agama Islam.

Penelitian ini termasuk dalam jenis penelitian kualitatif kepustakaan (library research). ${ }^{4}$ Pertimbangan akademiknya karena data yang dikumpulkan dari penelusuran literatur serta dokuemntasi-dokumentasi naratif atau uraian dan bukan berupa angkaangka, yaitu menghimpun data dengan cara menggunakan bahan-bahan tertulis, seperti : buku, artikel, surat kabar, majalah dan dokumen lainnya, yang sekirannya memiliki hubungan dengan tema penelitian. ${ }^{5}$

\section{Diskursus Pendidikan Perspektif Ki Hajar Dewantara}

Pendidikan sendiri yang sudah dijelaskan dalam bab sebelumnya menurut Ki Hajar Dewantara terhadap lima asas pendidikan yang dikenal dengan sebutan pancdharma (kodrat alam, kemerdekaan, kebudayaan, kebangsaan, dan kemanusiaan).

Kedua "pendidikan adalah pendidikan yang dilakukan dengan keinsyafan, ditujukan kearah keselamatan dan kebahagiaan manusia, tidak hanya bersifat laku "pembangunan" tetapi sering merupakan "perjuangan" pula. Pendidikan berarti memelihara hidup tumbuh kearah kemajuan, tidak boleh melanjutkan keadaan menurut alam kemarin. Pendidikan adalah usaha kebudayaan, berazaz keadaban, yakni mengajukan hidup agar mempertinggi drajat kemanusiaan. ${ }^{6}$

Ketiga "pendidikan adalah salah satu usaha untuk memberikan segala nilai-nilai kebatinan yang ada dalam hidup rakyat yang berbudayaan kepada tiap-tiap turunan baru (penyerahan kultur), tidak hanya berupa "pemeliharaan" akan tetepi juga dengan

\footnotetext{
${ }^{4}$ Lexy J. Moleong, Metodologi Penelitian Kualitatif (Bandung: Remaja Rosdakarya, 2015), 57.

${ }^{5}$ Noeng Muhadjir, Metode Penelitian Kualitatif, (Yogjakarta: Rake Saradin, 2014), 102.

${ }^{6}$ Abdul Mudjib \& Yusuf Mudzakkir, Ilmu Pendidikan Islam, (Jakarta: Kencana Prenada Media, 2006),
} 
maksud "memajukan "serta" mengembangkan" kebudaayn menuju kearah keluhuran hidup kemanusiaan. "keempat" pendidikan adalah segala usaha dari orang tua terhadap anak-anak dengan maksud menyongkong kemajuan hidpnya, dalam arti memperbaiki pertumbuhannya segala kekuatan rohani dan jasmani yang ada pada anak-anak karena kodrat-iradatnya sendiri."

Kelima "Lakunya pendidikan itu dalam umumnya dapat bersifat 3 macam, yaitu pembiasaan (untuk anak-anak kecil), pengajaran dengan mempergunakan fikiran (untuk anak-anak besar, umur 7 sampai 14 tahun)dan pendidikan budi pekerti dengan "laku" serta "ilmu" dengan peraturan ketertiban yang keras, (disiplin) ristimewa "selfdisiplin" untuk anak-anak dewasa, sampai 21 tahun.

Sesuai pengertian dengan karakter menurut Ki Hajar Dewantara di atas Masnur Muslih menggungkapkan bahwa pendidikan karakter adalah pendidikan budi pekerti ples, yaitu yang melibatkan aspek teori pengetahuan (cognitive), perasaan (felling), dan tindakan (action). Senada juga diungkapkan oleh Heri Gunawan bahwa arakter di kembangkan melalui tahap peengetahuan (knowing), pelaksanaan (action), dan kebiasaan (habit). ${ }^{7}$ Tanpa tiga aspek ini, maka pendidikan karakter tidak akan efektif. Dan pelaksanaanya pun harus dilakukan secara sistematis dan berkelanjutan.

Selanjutnya secara khusus Ki Hajar Dewantara juga menerangkan bahwa budi pekerti atau karakter adalah "menyongkong perkembanagan hidup anak-anak, lahir dan batin, dari sifat kodratinya menuju kearah peradaban dalam sifatnya yang umum. Menganjur-anjurkan atau kalau perlu memerintahkan anak-anak untuk duduk yang baik, jangan berteriak-teriaka agar tidak mengganggu anak-anak yanglain, bersih bada dan pakaianya, hormat terhadap Ibu Bapak dan orang-orang tua lainnya, menolong teman-teman yang perlu ditolong, demikian seterusnya itulah semuanya sudah merupakan "pen"gajaran budi pekerti."

\section{Pembentukan Karakter dalam Pendidikan Islam Perspektif Ki Hajar}

Sebelum membahas sebagaimana cara membentuk karakter anak maka penting untuk mengetahui sebagaimana dasar jiwa anak tersebut. Dasar jiwa anak menurut Ki Hajar Dewantara adalah "keadaan jiwa yang asali menurut kodratnya sendiri sebelum ada pengaruh dari luar. Jadi yang dibawah oleh anak ketika lahir di dunia ini. Yang terdapat beberapa aliran diantaranya yaitu aliran tabula rasa yakni pendidik berkuasa untuk membentuk watak dan karakter anak didik. Kemudian aliran negative yakni peserta didik dasrnya memiliki watak dan karakter sejak lahir sehingga pendidik tidak dapat merubah watak atau karakter melainkan pendidik hanya bisa mengawasi. Sedangkan aliran konvergensi ialah aliran yang mengatakan bahwa peserta didik sejak lahir memiliki watak yang baiak dan buruk, dan tugas pendidik adalah menebalkan watak yang baik dan menyuramkan watak yang buruk.

Istilah metode secarah sederhana sering diartikan cara yang cepat dan tepat. Menurut akhmad tafsir jika dipahami dari asal kata method (bahasa inggris) ini

${ }^{7}$ Heri Gunawan, Pendidikan Karakter Konsep dan Implementasi, (Bandung: Alfaberta, 2014), 28 
mempunyai pengertia yang lebih khusus, yakni cara yang cepat dan tepat dalam mengerjakan sesuatu.

Metode pendidikan karakter adalah jalan atau cara yang dapat ditempuh untuk menyampaikan bahan atau materi pendidikan karakter kepada anak didik agar tewujud kepribadian berkarakter. Selajan dengan itu alat pendidikan karakter, yaitu segala sesuatau yang dapat digunakan untuk mencapai tujuan pendidikan karakter. ${ }^{8}$

Sedangkan menurut Ki Hajar Dewantara bahwa peralatan pendidikan adalah alatalat yang pokok dan cara-cara mendidik. Cara atau metode itu menurut Ki Hajar Dewantara antara lain dapat melalui pembiasaan, keteladanan, pengajaran, reward and punishment serta pemberian pengalaman

Namun, ada kaum pendidik yang tidak mufakat dengan adanya salah satu bagian dari pada yangtermaktub itu. Misalnya pendidik dari pihak "pendidikan bebas" tidak suka memakai alat yang nomor 4 (perintah, paksaan dan hukuman). Seringkali pendidik mementingkan sesuatu bagian yang pada umumnya memilih cara-cara itu dihubungkan dengan umurnya anak didik.

Berhubung dengan alat-alat atau cara pendidikan yang dihubungkan dengan umur kanak-kanak, maka dibawah ini di sajikan pemakaian cara-cara sesuai dengan umur itu: ${ }^{9}$

1. Masa kanak-kanak : cara no.1 dan no.2. Waktu pertama (1-7 tahun). Di namakan masa kanak-kanak

2. Masa ke 2 : cara no.3 dan no.4. Waktu ke-2 (7-14 tahun), yakni masa pertumbuhan jiwa fikiran.

3. Masa ke 3 : cara no.5 dan no.6. masa ke-3 (14-21 tahun) dinamakan masa terbentuknya budi pekerti atau sosial periode.

Penjelasan diatas menunjukan bahwa pembentukan karakter Ki Hajar Dewantara dilakukan sejak usia dini yaitu umur satu tahun. Hal ini menyatakan bahwa dasar pendidikan karakter, sebaiknya diterapkan sejak usia kanak-kanak atau yang biasa disebut para ahli psikologi sebagai usia emas (golden age) karena usia ini terbukti sangat menentukan kemampuan anak dalam mengembangkan potensinya.

Berkaitan dengan metode diatas bahwa Ki Hajar Dewantara membagi beberapa masa sesiai dengan umur anak, maka pengajaran budi pekerti atau karakter juga memiliki beberapa tingkatan sesuai dengan umur anak-anak.

\section{Momong, Ngerti, dan Syariat}

Momong dalam bahasa jawa berarti merawat dengan tulus dan penuh kasih sayang serta mentranformasi kebiasaan-kebiasaan atau membiasakan hal-hal yang baik disertai dengan do'a dan harapan agar kelak buah rawatan dan kasih sayangnya menjadi anak yang baik dan selalu dijalan kebenaran dan keutamaan. ${ }^{10}$

8 Anas Salahudin, Irwanto Alkrienciechie, Pendidikan Karakter Pendidikan Berbasis Agama dan Budaya Bangsa, (Bandung: Pustaka Setia. 2013), 218

${ }^{9}$ Ki Hajar Dewantara, Wasita, Jilid I/ No. 6 Edisi Maret 1929.

10 Suparto Rahardjo. Ki Hajar Dewantara Biografi Singkat 1889-1959, (Jogjakarta: Garasi, 2015), 71 
Metode Ngerti adalah tugas sorang guru atau pendidik untuk memberikan pengertian yang sebaik-baiknya kepada anak didik. Seorang guru harus memberikan didikan kepada anak tentang bagaiman cara bersikap dan bertingkah laku dengan cara yang sopan dan santun, memprihatinkan tata krama, dan taat pada aturan.

Sedangkan syariat adalah yang dipakai untuk anak-anak kecil dan harus diartikan sebagai pembiasaan bertingkah laku serta berbuat menurut peraturan atau kebiasaan yang umum. Pengajaran syariat ini digunakan pada taman kanak-kanak dengan menggunakan pengajaran panca indra dan permainan. Untuk bagian "taman indria"dan"taman anak", bagi anak yang berumur 5-8 tahun segala segala pengajaran berupa pembiasaan semata-mata yang bersifat "global" dan "spontan" atau "occasiona".

Sehubungan dengan keteladanan dalam metode di atas maka Menurut Anwar Masy'ari Akhlak yang baik itu tidak dapat dibentuk dimasyarakat dengan pelajaran, dengan intruksi-intruksi dan larangan-larangan sebab tabi'at jiwa untuk menerima keutamaan-keutamaan ini telah cukup seorang guru mengatakan: kerjakan ini dan jangan kerjakan ini". Menanamkan sopan santun yang berubah sangat memerlukan pendidikan yang panjang dana harus ada pendekatan yang khusus. Pendidikan itu tidak akan sukses melainkan harus diusahakan dengan contoh dana teladana yang baik.

\section{Among, Ngersa, dan Hakikat}

Among dalam bahasa jawa berarti memberi contoh tentang baik buruk tanpa harus mengambil hak anak agar anak bisa tumbuh dan berkembang dalam suasana batin yang merdeka.

Metode Ngrasa adalah mengajak anak didik untuk berusaha secara maksimal untuk memahami, menghayati, dan merasakan tentang semua ilmu pengetahuan yang telah dikuasainya. Dalam hal ini, maka Ki Hajar Dewantara membiasakan kepada anak didik untuk dapat mempertanggung jawabkan segala sesuatau yang dilakukanya. ${ }^{11}$

Sedangkan pengajaran hakikat adalah kenyataan atau kebenaran yang mengandung maksud memberi pengertian kepada anak-anak, agar menjadi insyaf serta sadar tentang segala kebaikan dan kebalikannya. Pengajaran ini bermaksud agar anakanak jangan sampai terikat dengan pembiasaan dan tidak mengetahui akan maksud dan tujuan yang sebenarnya.

Sesuai pengajaran di atas Muzaiyana mengatakan bahwa Hakikat secara harfiyah berarti "yang nyata", 'yang benar" dan 'yang sejati". Sesuatu itu diketahui hakikatnya ketika telah menunjukan kepastiannya yang telah tetap, sehingga tidak dapat diingkari lagi. Dalam bahasa inggris. Kata haqiqah atau haqq adalah berarti the truth dan the reality yang artinya adalah kebenaran, kenyataan. Sesuatu yang nyata kehidupan yang benar atau keadaan yang sebenarnya dan senyatanya. ${ }^{12}$

\section{Ngemong, Nglakoni, dan Tarikat}

11 Ki Hajar Dewantara, Bagian Pertama Pendidikan (Yogjakarta: Majlis Luhur Persatuan Tamansiswa, 1962), 29.

12 Muzaiyana dkk, Akhlak tasawuf(Surabaya:UIN Sunan Ampel. 2014), 281 
Ngemong dalam bahasa jawa berarti proses proses untuk mengamati, merawat dan menjaga agar anak mampu mengembangkan dirinya, bertanggung jawab dan disiplin berdasar nilai-nilai yang telah diperoleh sesuai dengan kodratnya. Metode Ngelakoni adalah upaya untuk mengajak anak didik memikirkan untung dan rugi sebelum mengambil keputusan untuk melakukan sesuatu. ${ }^{13}$

Sedangkan tarikat adalah melakukan perbuatan dengan sengaja supaya melatih diri untuk melaksanakan kebaikan meskipun sukar dan bert. Tarikat ini seperti bermcam-macam perbuatan seperti berpuasa, berjalan kaki menuju tempat yang jauh, mengurangi tidur dan makan serta menekan berbagai bahwa nafsu pada umumnya. Untuk bagian "teman dewasa", bagi anak-anak yang berumur 14-16 tahun adalah periode atau waktunya anak-anaj untuk meneruskan pancaharian pengertian mulai melatih diri terhadap segala laku yang sukar dan berat dengan niat yang disengaja.

\section{Analisis tentang Relevansi Metode Pembentukan Karakter Ki Hajar Dewantara dengan Pendidikan Islam}

Seperti yang telah diterangkan Ki Hajar Dewantara tentang budi pekerti atau karakter yaitu "tringa (ngerti, ngersa, nglakoni)" maka Menurut Anas Salahuddin dan Irwanto Alkrienciehie bahwa manusia secara kodrati di karuniai tiga potensi, yaitu : Akal (kognisi); Indriawi (afeksi); dan Hati (nurani)

Tiga potensi itu di jelaskan Allah SWT. Dalam firman-Nya:

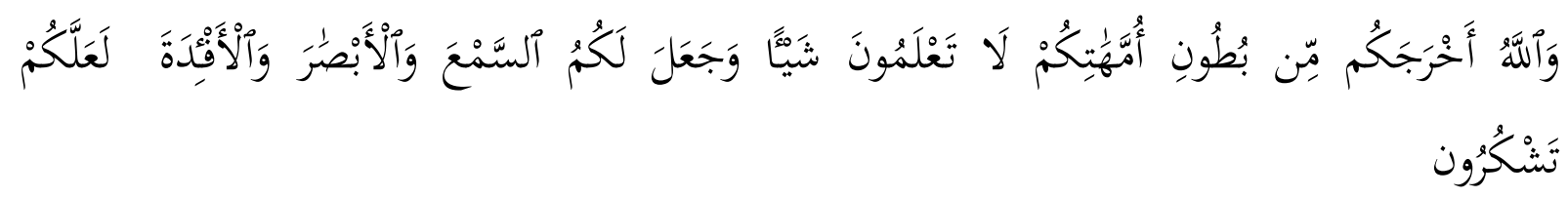

Dan Allah mengeluarkan kamu dari perut ibumu dalam keadaan tidak mengetahui suatu pun, dan dia memberikan pendengaran, penglihatan dan hati nurani, agar kamu bersyukur. QS An-Nahl (16):78)

Sebagai konklusinya, hakikat pendidikan karakter berisi islam adalah keselarasan amtara akal (IQ), Emosi (EQ), dan Nurani (SQ). Kemudian menurut Nur Uhbiati dalam buku ilmu pendidikan islam yang di kutip Anas Salahuddin dlam bukunya pendidikan karakter pendidikan berbasis agama dan budaya bangsa menjelaskan tentang bagaimana Mendidikn dengan cara memberikan kebebasan kepada peserta didik sesuai dengan kebutuhannya. Seperti dalam hadist yang artinya. "Nabi Muhammda SAW. Menjelaskan "tidak seorang pun di lahirkan kecuali menurut fitrahnya" pemberian kebebasan itu tentu tidak mutlak (tidak terbatas), tetapi dalam batas-batas tertentu sesuai dengan kebutuhan.

Sesuai dengan metode Ki Hajar Dewantara Ngerti, Ngersa, dan Nglakoni maka Anas Salahuddin juga menjelaskan proses pendidikan karakter di ajarkan untuk mengupayakan keberhasilan dalam pendidikan karakter, ada beberapa proses pendidikan karakter yang di ajarkan, yaitu:

${ }^{13}$ Ki Hajar Dewantara, Bagian Pertama Pendidikan, 89. 
1. Knowing the good (ta'lim), yaitu tahap memberikan pemahaman tentang nilai-nilai agama/akhlak melalui dimensi akal, rasio dan logika dalam setiap bidang studi.

2. Loving the good (tarbiyah), yaitu tahap menumbuhkan rasa cinta dan rasa butuh terhadap nilai-nilai kebaikan, melalui dimensi emosional, hati, atau jiwa.

3. Doing the good (taqwim), yaitu tahap mempraktikan nilai-nilai kebaikan, melalui dimensi perilaku dan amaliah

Metode dalam pendidikan yang di jelaskan Ki Hajar Dewantara di antaranya terbagi dalam beberapa tingkat yang sudah di jelaskan dalam bab sebelumnya. Adapun tingkatan-tingkatan yang di maksud meliputi:

1. Pengajaran syari'at kita pakai untuk anak-anak kecil dan harus kita artikan sebagai pembiasaan bertingkah-laku serta berbuat menurut peraturan atau kebiasaan yang umum. Si-pamong memberi contoh, anjuran atau perintah anak-anak untuk melakukan apa yang diinstrusikan oleh gurunya. Namun keterangan-keterangan atau penjelasan-penjelasan belum waktunya diberikan, karena anak-anak belum mempunyai kesanggupan untuk berfikir. ${ }^{14}$

Sehubungan dengan metode yang pertama di atas islam juga menjelaskan bagaimana cara mendidik dalam islam melalui pembiasaan ataua teladan sebagaimana yang telah ada firman Allah (Al-Qur'an) surah Al-Maidah 31 dan surah Al-Ahzab ayat 21, terkait keteladanan (peniruan).

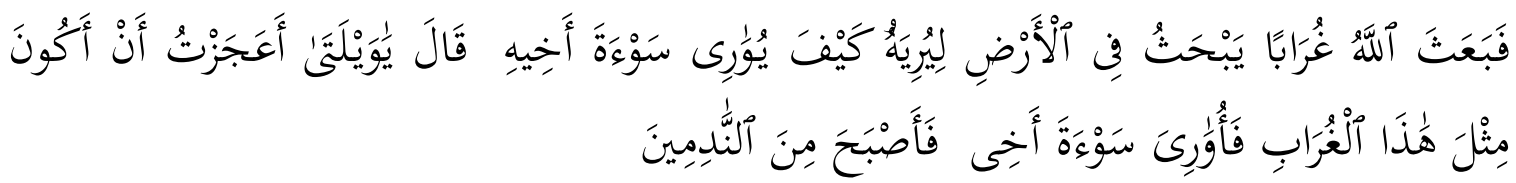

Kemudian Allah menyuruh seekor burung gagak menggali-ngali di bumi untuk memperlihatkan (qalbi) bagaimana dia seharusnya menguburkan mayat saudarannya, Qabil berkata: "aduhai celaka aku, mengapa aku tidak mampu berbuat seperti burung gagak ini, lalu akau dapat menguburkan mayat saudaraku ini?" karena itu jadilah dia seorang diantara orang-orang yang menyesal. ${ }^{15}$

2. Tingkatan yang kedua ialah tingkatan "hakikat" yang berarti "kenyataan" atau "kebenaran" dan yang mengandung maksud memberi pengertian kepada anak-anak, agar mereka menjadai "insyaf" serta "sadar" tentang segala kebaikan dan kebalikankebalikannya. Pengajaran "hakikat" ini kita pakai untuk anak-anak di dalam priode "akil-balignya", yakni waktu berkembangnya 'akal" atau kekuatan berfikir. ${ }^{16}$ Disitulah waktu kita memberi keinsyafan dan kesadaran tentang berbagai kebaikan atau kejahatan, namun selalu atas dasar pengetahuan, kenyataan dan kebenaran.

\footnotetext{
${ }^{14}$ Suparto Rahardjo. Ki Hajar Dewantara, 68

15 Q.S. Al-Maidah 31

16 Nadjamuddin Ramly, Membangun Pendidikan Yang Memberdayakan dan Mencerahkan, (Jakarta: Grafindo, 2016), 71
} 
Jangan sampai anak-anak terus terikat kepada "pembiasan-pembiasaan" dengan tidak mengetahui akan maksud dan tujuan yang sebenar-benarnya.

Dalam hal ini islam juag mengajarkan cara mendidik yang sama untuk memberikan pengertian-pengertian yang baik agar anak didik mengetahui apa yang harus dilakukan. Berupan nasehat-nasehat seperti yang di contohkan dan di jelaskan Allah dalam firman-Nya surah Al-luqman diantaranya sebagai berikut:

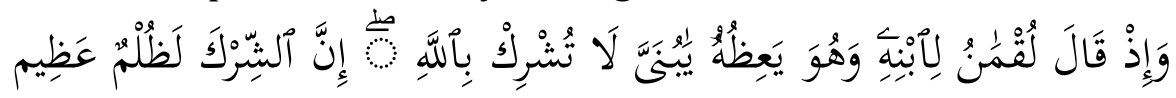

Dan (ingatlah), ketika Luqman berkata kepada anaknya, diwaktu ia memberipelajaran kepadannya: 'Hai anakmku, janganlah kamu mempersekutukan Allah, sesungguhnya persekutukan (Allah) adalah benar-benar kezaliman yang besar. ${ }^{17}$

3. Tingkatan yang ketiga dalam sistem pemberian pengajaran menurut tradisi pendidikan agama islam yang dapat kita pakai dengan perubahan-perubahan yang perli ia tingkatkan "tarikat" yang lebih dikenal dengan sebutan tirakat. 'tarikat", berarti "laku", yakni perbuatan yang dengan sengaja kita lakukan dengan maksud supaya kita melatih diri untuk melaksanakan berbagai kebaikan bagaimanapun sukarnya atau beratnya. Inilah latihan bagi anak-anak yang mulai dewasa untuk memaksa dan menekan atau memerintahkan dan menguasai diri pribadi.

Sehungan dengan tarikat diatas islam juga telah mencontohkan bagaimana laku yaitu tarikat itu sangat penting demi mencapai ilmu yang tinggi. Berkaitan dengan ini telah diceritakan tentang tarikat dalam surah Al-kahfi ayat 60.

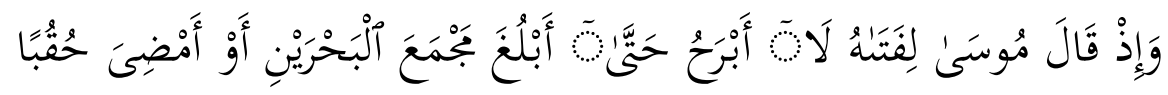

Dan (ingatkanlah peritiwa) ketika Nabi Musa berkata kepada temannya: aku tidak akan berhenti berjalan sehingga akau sampai di tempat pertemuan dua laut itu atau akau berjalan terus bertahun-tahun. ${ }^{18}$

Setelah beberapa cara yang digunakan $\mathrm{Ki}$ Hajar Dewantara untuk membentuk karakter maka tujuan pembentukan karakter atau nilai yang terkandung dalam pembentukan karakter Ki Hajar Dewantara adalah sebagai berikut:

1. Bersahabat/komunikatif, yaitu tindakan yang memperlihatkan rasa senang bicara, bergaul, dan bekerja sama dengan orang lain. Nilai ini dididik oleh $\mathrm{Ki}$ Hajar Dewantara melalui metode Ngerti agar menjadikan anak cakap dan bergaul dengan orang lain.

Kaitannya dengan ini maka islam juga menjelaskan bagaimana manusia satu dengan yang lain harus bersahabat dan saling komunikasi dengan baik. Seperti firman Allah dalam surah Al-hujurat ayat 13.

${ }^{17}$ Q.S. Al-Luqman 13

${ }^{18}$ Q.S. Al-Kahfi 60 


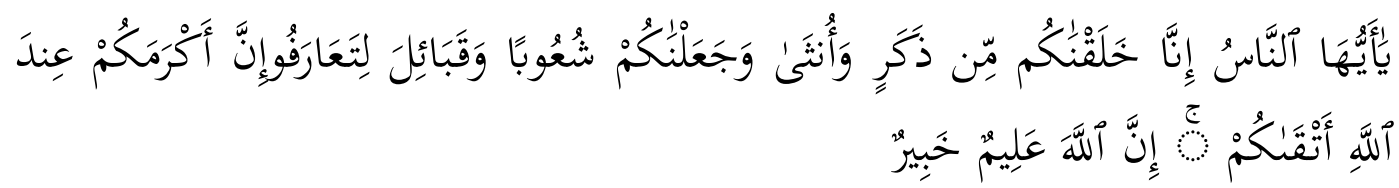

Hai manusia, sesungguhnya kami menciptakan kamu dari serang laki-laki dan perempuan dan menjadikan kamu berbangsa-bangsa dan bersuku-suku supaya kamu saling kenal mengenal. Sesungguhnya orang yang paling mulia diantaranya kamu disisi Allah ialah orang yang paling takwa diantara kamu. Sesungguhnya Allah Maha Mengetahui lagi Maha Mengenal. ${ }^{19}$

2. Tanggung jawab, yaitu sikap dan prilaku seseorang untuk melaksanakn tugas dan kewajibannya, yang seharusnya dia lakukan terhadap diri sendiri, masyarakat, lingkungan, (alam,karakter dimulai dalam sosial dan budaya), negara dan Tuhan yang Maha Esa. Nilai ini di didik Ki Hajar Dewantara melalui metode Tringa untuk membiasan anak agar memiliki karakter tanggung jawab.

Dalam hal ini islam juga menjelaskan tentang bagaimana manusia harus memiliki sikap tanggung jawab sebagaimana firman Allah dalam surah An-Nahl ayat 9.

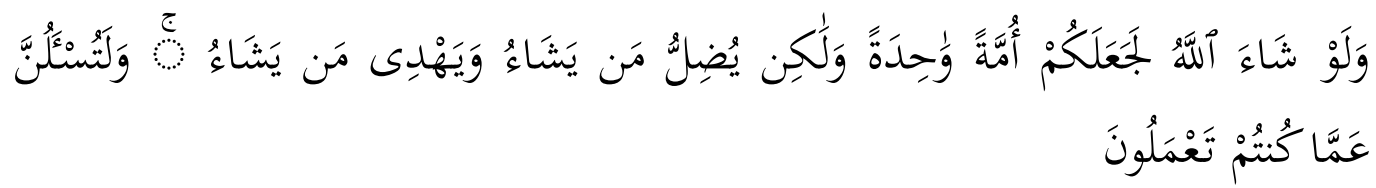

Dan kalau Allah menghendaki, niscaya Dia menjadikan kamu satu umat (saja), tetapi Allah menyesatkan siapa yang dikehendaki-Nya dan memberi petunjuk kepada siapa yang dikehendaki-Nya. Dan sengguhnya kamu akan ditanya tentang apa yang telah kamu kerjakan. ${ }^{20}$

Pada hari kiamat kelak, kalian benar-benar akan ditanyai untuk dihisab dan diberi balasan, bukan untuk dimintai jawaban ataupun keterangan. Ayat ini membuktikan bahwa semua perbuatan manusia baik dan buruk pasti akan dimintai pertanggung jawaban. Karena itu manusia harus siap bertanggung jawab atas apa yang dilakukan. Sebagaimana firman Allah surah Al-Mudasir ayat 38 yang artinya: tiap-tiap dari bertanggung jawab atas apa yang diperbuatnya.

3. Mandiri, adalah sikap dan prilaku tidak tergantung pada orang lain dalam menyelsaikan berbagai tugas maupun persoalan. Namun hal ini bukan tidak boleh bekerja sma secara kolaboratif, melainkan tidak boleh melemparkan tugas dan tanggung jawab kepada orang lain. ${ }^{21}$ Berhubungan dengan nilai karakter mandiri maka islam juga menjelaskan anjuran bersikap mandiri. Sebagaimana Rasulullah SAW menjelaskan agar bersikap mandiri seperti yang diriwayatkan oleh Bukhari yaitu:

Dari Abu Abdillah yaitu a-ubair bin Al-Awwam r.a., katannya: "Rasulullah s.a.w bersabda: "niscayalah jikalu seseorang dari engkau semua itu mengambil

\footnotetext{
${ }^{19}$ Q.S. Al-Hujurat 13

${ }^{20}$ Q.S. An-Nahl , 93

${ }^{21}$ Nadjamuddin Ramly, Membangun Pendidikan, 30
} 
tali0talinya untuk mengikat lalu ia datang di gunung, kemudian ia datang kembali di negrinya dengan membawa sebongkokan kayu bakar di atas punggungnya, lalu menjualnya kemudian dengan cara sedemikian itu Allah menahan wajahnya yakni dicukupi kebutuhannya, maka hal yang semacam itu adalah lebih baik baginya dari pada meminta-minta sesuatu pada orang-orang, baik orang itu suka memberinya atau menolaknya."(H.R. Bukhari)

Mandiri adalah sikap tidak tergantung pada orang lain. Dan hadist di atas telah membuktikan bahwa nilai karakter mandiri yang di bentuk Ki Hajar Dewantara ternyata islam pun telah mengajarkan.

4. Disiplin, yaitu tindakan yang menunjukkan prilaku tertib dan patuh pada berbagai ketentuan dan peraturan. ${ }^{22}$ Sedangkan disiplin menurut Ki Hajar Dewantara yang dirancang dibentuk dalam metode nglakoni adalah peraturan tata tertib yang dilakukan dengan tegas dan keras. Biasannya disiplin itu diterimah orang dengan ihlas dan rela, walaupun ia merasakan beratnya. Hal ini disebabkan karena dengan suka rela itu telah memusatkan dirinya ke dalam kesatuan yang disiplin. ${ }^{23}$

Dalam hal ini islam menerangkan disiplin sebagai patuh dengan pemimpin. Karena pada dasarnya disiplin adalah taat tata tertib sesuai dengan peraturan yang ada. Sebagimana dalam surah An-Nisa ayat 59.

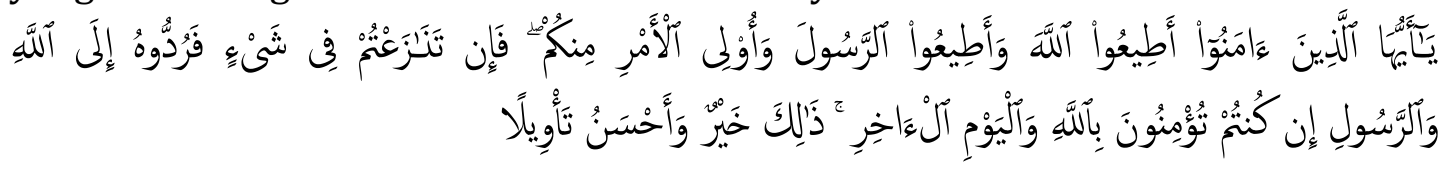

Hai orang-orang yang beriman, taatilah Allah dan tatilah Rasul-Nya, dan ulil amri di antara kamu. Kemudian jika kamu berlainan pendapat tentang sesuatu, maka kembalikanlah ia kepada Allah (Al-Qur'an) dan Rasul (sunnahny), jika kamu benar-benar beriman kepada Allah dan hari kemudian. Yang demikian itu lebih utama (bagimu) dan lebih baik akibatnya. ${ }^{24}$

Berdasarkan uraian di atas dapat dipahami bahwasannya pembentukan karakter yang diungkapkan Ki Hajar Dewantara itu selaras dengan pembentukan karakter dalam pendidikan islam, baik segi konsep yang meliputi pengertian dan cara maupun nilai-nilai karakter yang diharapkan dalam mendidik karakter anak.

\section{Kesimpulan}

Pendidikan karakter menut Ki Hajar Dewantara adalah bersatunya gerak fikiran, perasaan, dan kehendak, atau kemauan yang lalu menimbulkan tenaga budi pekerti atau karakter disini yang dimaksud ialah untuk menyongkong tumbuh kembangnya anakanak dari sifat kodratinya menuju sifat yang baik. Dalam pembentukan karakter Ki Hajar Dewantara menjelaskan tentang tiga cara dengan bahasa yang berbeda-beda. Yakni Syari'at, Ngerti, atau Among, Hakikat, Ngrasa dan Ngemong. Trikat, Ngelakoni, dan Momong. Kemudian melalui beberapa metode diatas Ki Hajar Dewantara bertujuan

22 Salahuddin Anas, Irwanto Alkrienciche, Pendidikan Karakter Pendidikan Berbasis Agama dan Budaya Bangsa (Bandung: PT.Remaja Rosdakarya, 2018), 30.

${ }^{23}$ Ki Hajar Dewantara, Wasita, 453.

${ }^{24}$ Q.S. An-nisa , 59 
untuk membentuk nilai karakter cepat dan tepat dalam mengambil keputusan, komunikatif, mandiri, disiplin, dan tanggung jawab.

Pendidikan karakter adalah bersatunya gerak fikiran, kemauan kemudian akan menimbulkan tenaga, sehubungan dengan ini islam juga menjelaskan bahwa manusia mempunyai tiga potensi yaitu Akal, Emosi, dan Nurani, menurut pendidikan islam keselarasan antara ketiga itu akan menimbulkan budi pekerti yang baik.

Terdapat relevansi antara pembentukan karakter menurut Ki Hajar Dewantara dengan pemikiran Islam. ki Hajar Dewantara menjelaaskan bahwa dalam pembentukan karakter terdapat beberapa tingkatan di antarannya yang pertama adalah syari'at dimana maksud dari syari'at itu sendiri adalah membentyk karakter anak didik melalui pembiasaan atau memberikan contoh melalui teladan guru. Sebagaimana surat ALAHZAB yang menerangkan suri tauladan dari nabi Muhammad SAW. Kemudian tingkat hakikat. Tingkat hakikiat ini adalam membentuk nilai karakter melalui nasehat-nasehat. Yakni memberikan pengertian kepada anak yang sudah baligh tentang hal yang baik dan buruk. Sebagaimana dengan surah lukman yang menjelaskan nasehat kepada anaknya. Tingkatan yang terakhir yaitu tarikat. Tingkatan tarikat ini membentuk melalui laku. Dalam hanl ini pula islam telah menjelaskan sebagaimana dalam firman Allah SWT dalam surah Al-kahfi

\section{Daftar Rujukan}

Anas, Salahuddin, Irwanto Alkrienciche, Pendidikan Karakter Pendidikan Berbasis Agama dan Budaya Bangsa. Bandung: PT.Remaja Rosdakarya, 2018.

Dewantara, Ki Hajar. Bagian Pertama Pendidikan. Yogjakarta: Majlis Luhur Persatuan Tamansiswa, 1962.

Dewantara, Ki Hajar. Wasita, Jilid I/ No. 6 Edisi Maret 1929.

Gunawan, Heri. Pendidikan Karakter Konsep dan Implementasi. Bandung: Alfaberta, 2014.

Kusuma, Dharma dkk, Pendidikan Karakter. Bandung: Remaja Rosdakarya. 2012.

Moleong, Lexy J. Metodologi Penelitian Kualitatif. Bandung: Remaja Rosdakarya, 2015.

Mudjib, Abdul \& Yusuf Mudzakkir, Ilmu Pendidikan Islam. Jakarta: Kencana Prenada Media, 2006.

Muhadjir, Noeng. Metode Penelitian Kualitatif. Yogjakarta: Rake Saradin, 2014.

Muzaiyana dkk, Akhlak tasawuf. Surabaya:UIN Sunan Ampel. 2014.

Rahardjo, Suparto. Ki Hajar Dewantara Biografi Singkat 1889-1959. Jogjakarta: Garasi, 2015.

Ramly, Nadjamuddin. Membangun Pendidikan Yang Memberdayakan dan Mencerahkan,. Jakarta: Grafindo, 2016.

Wibowo, Agus. Pendidikan Karakter Strategi mebangun karakter bangsa berperadaban. Yogjakarta: Pustaka Pelajar. 2012.

Zubaidi, Desain karakter. Jakarta: Preneda Media Group, 2011. 